\title{
PERANAN KELUARGA DALAM PROSES PENANAMAN KEDISIPLINAN TERHADAP REMAJA DI DUSUN KRAJAN, DESA GEMBONG, KECAMATAN ARJOSARI, KABUPATEN PACITAN TAHUN 2015
}

\author{
Erma Septanti*
}

\begin{abstract}
Abstrak
$\mathrm{P}$ eranan keluarga merupakan salah satu faktor penting dalam megembangkan kedisiplinan belajar agar remaja lebih termotivasi untuk berdisiplin diri terhadap dirinya sebagai seorang pelajar. Dengan demikian, penelitian ini bertujuan untuk mendeskripsikan kedisiplinan belajar remaja dan peranan keluarga dalam proses penanaman kedisiplinan belajar terhadap remaja di Dusun Krajan, Desa Gembong, Kecamatan Arjosari, Kabupaten Pacitan tahun 2015. Penelitian ini termasuk penelitian deskriptif kualitatif, Pengumpulan data menggunakan metode observasi partisipatif, wawancara semi terstruktur, dan dokumentasi.Analisis data menggunakan reduksi data, penyajian data, dan penarikan kesimpulan dan verifikasi. Hasil penelitian menunjukkan bahwa kedisiplinan belajar remaja di Dusun Krajan, Desa Gembong, Kecamatan Arjosari, Kabupaten Pacitan tahun 2015 belum disiplin. Remaja laki-laki akan belajar ketika diperintah terlebih dahulu dari keluarga atau orang tua, ketika ada tugas sekolah atau PR (Pekerjaan Rumah), dan akan menghadapi ulangan. Tidak ada kesadaran dari remaja laki-laki sendiri untuk belajar. Peranan keluarga dalam proses penanaman kedisiplinan terhadap remaja yaitu membimbing, mengarahkan, mengawasi, membiasakan dan menasihati. Peranan tersebut diimplementasikan dengan cara keluarga atau orang tua turut andil dalam kegiatan belajar anaknya, mengawasi anaknya belajar sampai selesai, menerapkan jadwal belajar, dan memberikan motivasi terhadap remaja untuk selalu giat belajar.
\end{abstract}

\section{Kata Kunci: Keluarga, Kedisiplinan, Remaja.}

* Mahasiswa Prodi PPKn IKIP PGRI Madiun 
PENDAHULUAN

Kompleksitas

masalah

kehidupan mengalami perubahan yang cepat sekali di zaman globalisasi ini. Fenomena-fenomena yang terjadi banyak mengakibatkan para remaja ikut terpengaruh dengan kegiatan yang tidak bermanfaat yang berpengaruh pada pendidikannya. Usia remaja disebut sebagai masa krisis dan usia bermasalah, yaitu perubahan terjadi sangat drastis dan mengakibatkan terjadinya kondisi yang serba tanggung dan diwarnai oleh kondisi psikis yang belum mantap.

Pada kehidupan sehari-hari, masih banyak remaja yang mengalami permasalahan dalam belajarnya. Faktor-faktor yang mempengaruhi tersebut dapat dibagi menjadi dua yaitu faktor internal dan faktor eksternal. Faktor internal terdiri dari faktor fisiologis dan faktor psikologis, sedangkan faktor eksternal terdiri dari faktor lingkungan keluarga, lingkungan sekolah, dan lingkungan masyarakat.

Sebagai contoh perilaku remaja yang dapat menurunkan kedisiplinan belajarnya yaitu anak nakal, sulit diatur, suka melawan, sering membolos sekolah, tawuran, penggunaan narkoba, melihat televisi dan duduk-duduk santai atau nongkrong pada saat jam belajar di sekolah maupun dirumah dan yang tidak kalah pentingnya yaitu penggunaan media elektronik seperti telepon genggam atau handphone(selanjutnya dibaca HP) di kalangan remaja.

Perkembangan teknologi HP yang begitu pesat, jelas sekali mempengaruhi perilaku pengguna HP tersebut. HP yang dilengkapi berbagai fitur atau aplikasi memudahkan setiap pengguna untuk berinteraksi dengan lawannya. Apalagi HP remaja saat ini dilengkapi dengan sosial media seperti facebook, twitter dan lainlain, mengakibatkan remaja lebih banyak menghabiskan aktivitasnya untuk menggunakan HP. Hal tersebut dapat mempengaruhi kedisiplinan belajar remaja tersebut. Remaja akan lebih sering menggunakan waktu dengan bermain HP daripada waktu untuk belajarnya. Jika remaja mudah terpengaruh dengan kondisi tersebut, dapat berpengaruh juga pada kedisiplinan atau keteraturan dalam belajarnya. 
Untuk mengatasi hal tersebut, salah satu upaya yang dilakukan yaitu melalui pendidikan.UndangUndang Dasar 1945 Bab XA tentang Hak Asasi Manusia Pasal 28C ayat (1) menyebutkan bahwa "Setiap orang berhak mengembangkan diri melalui pemenuhan kebutuhan dasarnya, berhak mendapat pendidikan dan memperoleh manfaat dari ilmu pengetahuan dan teknologi, seni, dan budaya, demi meningkatkan kualitas hidupnya dan demi kesejahteraan umat manusia(Majelis Permusyawaratan Rakyat, 2009: 19). Oleh karena itu, setiap orang berhak untuk mengembangkan diri dan mendapatkan pendidikan.

Hal ini juga sesuai dengan Undang-Undang Nomor 20 Tahun 2003 tentang Sistem Pendidikan Nasional Pasal 1 ayat (1)."Pendidikan adalah usaha sadar dan terencana untuk mewujudkan suasana belajar dan proses pembelajaran agar peserta didik secara aktif mengembangkan potensi dirinya untuk memiliki kekuatan spiritual keagamaan, pengendalian diri, kepribadian, kecerdasan, akhlak mulia, serta keterampilan yang diperlukan dirinya, masyarakat, bangsa, dan negara(Majelis Permusyawaratan Rakyat, 2003: 2). Pendidikan dilaksanakan di lingkungan keluarga, sekolah, dan masyarakat. Dengan demikian, keluarga merupakan salah satu lembaga yang mengemban tugas dan tanggung jawab dalam pencapaian tujuan pendidikan umum (Moh. Shocib, 2010: 2) Keluarga merupakan salah satu lembaga pengembangan tugas dan tanggung jawab pendidikan pertama. Agar dapat melaksanakan tugas dan tanggung jawab yang benar, peran keluarga sangatlah penting. Keluarga adalah tempat anak berasal dan mempengaruhi remaja setiap hari dalam kehidupannya sampai dewasa.

Tujuan pendidikan adalah mengupayakan subjek peserta didik menjadi pribadi yang utuh dan terintegrasi. Untuk mencapai tujuan ini, tugas dan tanggung jawab keluarga adalah menanamkan disiplin, menciptakan situasi dan kondisi yang memuat iklim yang dapat dihayati anak untuk memperdalam dan memperluas berbagai makna yang menjadi pedoman dalam kehidupan anak. 
Salah satu aspek untuk mendorong dan mengembangkan kepribadian anak secara utuh adalah disiplin.

Karakter disiplin adalah salah satu karakter yang baik dan wajib dimiliki oleh seseorang, terutama bagi remaja. Karakter disiplin sangat penting bagi remaja terkait dengan pendidikan yang dijalaninya. Remaja akan memperoleh hasil belajar yang memuaskan apabila remaja mampu mengatur waktu dan kegiatan belajarnya. Disiplin dapat tumbuh dibina melalui latihan, pendidikan atau penanaman kebiasaan dimulai sejak dalam lingkungan keluarga.

Pendidikan dalam keluarga memberikan keyakinan agama, nilai budaya yang mencakup nilai moral, peraturan pergaulan, pandangan hidup, dan sikap hidup yang mendukung kehidupan bermasyarakat, berbangsa dan bernegara. Peranan keluarga sangat penting dalam proses penanaman kedisiplinan terhadap remaja. Peranan keluarga dalam mendidik remaja membutuhkan keterlibatan dan tanggung jawab komplek, selaras dengan pertumbuhan anak dan tuntutan zaman. Peranan keluarga merupakan salah satu faktor penting dalam mengembangkan kedisiplinan belajar agar remaja lebih termotivasi untuk berdisiplin diri terhadap dirinya sebagai seorang pelajar.

Keluarga yang ada di Dusun Krajan, Desa Gembong, Kecamatan Arjosari, Kabupaten Pacitan mempunyai profesi pekerjaan dan kesibukan berbeda-bedasehingga peranan keluarga dalam proses penanaman kedisiplinan terhadap anak remajanya berbeda-beda pula. Dengan kesibukan orang tua yang berbeda-beda terkadang ada keluarga sangat peduli dengan kedisiplinan belajar anaknya, namun terkadang tidak terlalu memperdulikan kedisiplinan belajar anaknya.

$$
\text { Peran keluarga kaitannya }
$$
dalam proses penanaman kedisiplinan terhadap remaja sangat penting dan dibutuhkan mengingat usia remaja disebut sebagai masa krisis atau usia bermasalah terkait dengan pencarian jati dirinya.

\section{METODE PENELITIAN}

Penelitian ini dilaksanakan di Dusun Krajan, Desa Gembong, Kecamatan Arjosari, Kabupaten Pacitan.Waktu yang diperlukan 
dalam penelitian ini yaitu 5 bulan dari Maret sampai dengan Juli 2015.

Metode penelitian yang diterapkan dalam penelitian ini adalah metode kualitatif.Jenis penelitiannya adalah deskriptif.Dengan demikian, laporan penelitian berisi kutipan-kutipan data untuk memberikan gambaran penyajian laporan tersebut.

Penelitian kualitatif dalam hal ini menggunakan dua jenis sumber data yaitu sumber data primer dan sumber data sekunder. Data primer dalam penelitian ini adalah hasil wawancara secara langsung dengan keluarga yang memiliki anak usia remaja, kepala dusun, dan remaja laki-laki yang ada di Dusun Krajan, Desa Gembong, Kecamatan Arjosari, Kabupaten Pacitan. Sumber data sekunder untuk penelitian ini adalah dokumen dari arsip desa tentang kependudukan yang meliputi jumlah keluarga dan jumlah remaja di Dusun Krajan, Desa Gembong, Kecamatan Arjosari, Kabupaten Pacitan dengan rentang usia dari 12 sampai 21 tahun kecuali yang sudah menikah dan bekerja.

Teknik pengumpulan data dalam penelitian ini menggunakan teknik observasi, wawancara semi terstruktur, dan dokumentasi. Observasi atau pengamatan pada penelitian ini tentang kedisiplinan belajar remaja di Dusun Krajan, Desa Gembong, Kecamatan Arjosari, Kabupaten Pacitan pada waktu malam. Wawancara dalam penelitian ini dilakukan dengan keluarga, remaja laki-laki, dan kepala dusun dengan 9 pertanyaan untuk masingmasing keluarga dan kepala dusun, serta 6 pertanyaan untuk masingmasing remaja.

Analisis data dalam penelitian ini dilakukan secara interaktif dan berlangsung secara terus menerus sampai tuntas dari awal sampai akhir penelitian. Prosesnya dilakukan dengan cara reduksi data, penyajian data, dan verifikasi.

\section{HASIL DAN PEMBAHASAN}

1. Kedisiplinan Belajar Remaja Di Dusun Krajan, Desa Gembong, Kecamatan Arjosari, Kabupaten Pacitan Tahun 2015

Hasil observasi, wawancara, dan dokumentasi diperoleh data bahwa kedisiplinan belajar remaja laki-laki di rumah belum disiplin. Remaja laki-laki akan belajar 
ketika diperintah terlebih dahulu dari keluarga atau orang tua, ketikaada tugas sekolah atau PR (Pekerjaan Rumah), dan akan menghadapi ulangan. Tidak ada kesadaran dari remaja laki-laki sendiri untuk belajar. Selain itu, remaja laki-laki sering melakukan kegiatan duduk-duduk santai ataunongkrong saat jam belajar malam yaitu mulai dari pukul 19.00 WIB sampai dengan pukul 21.00 WIB sehingga hal tersebut dapat mengganggu kedisiplinan belajar remaja khususnya remaja laki-laki.

2. Peranan Keluarga dalam Proses Penanaman Kedisiplinan Belajar Remaja Di Dusun Krajan, Desa Gembong, Kecamatan Arjosari, Kabupaten Pacitan Tahun 2015

Peran keluarga kaitannya
dalam proses penanaman
kedisiplinan terhadap remaja
sangat penting dan dibutuhkan
mengingat usia remaja disebut
sebagai masa krisis.Disiplin dapat
dicapai dan dibentuk melalui
proses latihan.
melakukan disiplin
berulang-ulang

praktik disiplin sehari-hari. Dengan latihan dan membiasakan diri, disiplin akan terbentuk dalam diri dan disiplin telah menjadi kebiasaan.

Berdasarkan hasil wawancara disimpulkan bahwa peranan keluarga dalam proses penanaman kedisiplinan belajar terhadap remaja di Dusun Krajan, Desa Gembong, Kecamatan Arjosari, Kabupaten Pacitan tahun 2015 yaitu membimbing, mengarahkan, mengawasi, membiasakan dan menasihati.

Peran keluarga atau orang tua dalam membimbing, mengarahkan, dan mengawasi dalam kaitannya penanaman kedisiplinan belajar remaja yaitu dengan cara keluarga atau orang tua turut andil dalam kegiatan belajarnya, dengan cara mendampingi serta mengawasi kegiatan belajar sampai selesai. Pendampingan keluarga atau orang tua dalam kegiatan belajar remaja dimaksudkan agar keluarga atau orang tua dapat membantu remaja apabila remaja mendapatkan kesulitan dalam belajarnya. Selanjutnya, peran 
keluarga atau orang tua dalam membiasakan remaja kaitannya dengan penanaman kedisiplinan belajar remaja dapat dilakukan dengan cara keluarga atau orang tua selalu menerapkan jadwal belajar bagi remaja yaitu setelah salatisya sampai kurang lebih pukul 21.00 WIB.Peran keluarga atu orang tua dalam hal menasihati dilakukan dengan cara memberikan motivasi terhadap remaja untuk selalu giat belajar. Hal ini di dukung dari hasil observasi, wawancara, dan dokumentasi. Hasil penelitian ini juga mendapat dukungan dari teori-teori yang sesuai dengan kedisiplinan remaja dan peranan keluarga dalam proses penanaman kedisiplinan terhadap remaja.

Tujuan adanya peran keluarga dalam mendidik remaja, diantaranya remaja menjadi disiplin belajar, dan termotivasi untuk berprestasi, mengingat usia remaja merupakan usia bermasalah terkait dengan pencarian jati dirinya sehingga memerlukan perhatian, bimbingan, dan arahan untuk menemukan karakteristik jati
dirinya.Remaja perlu dibiasakan dan diarahkan tentang pentingnya disiplin belajar sehingga pada akhirnya dapat membentuk karakter remaja yang mempunyai sikap disiplin belajar yang tinggi yang siap menghadapi dunia kerja kelak ketika dewasa. Untuk langkah ke depannya lagi, keluarga atau orang tua yang ada di Dusun Krajan, Desa Gembong, Kecamatan Arjosari, Kabupaten Pacitan harus lebih giat melakukan penanaman kedisiplinan belajar pada diri remaja dengan cara menasihati, mengarahkan, mengawasi, membiasakan dan menasihati agar dapat meningkatkan sikap disiplin belajarnya.

\section{SIMPULAN}

Berdasarkan pembahasan di atas, dapat disimpulkan tentang Peranan Keluarga Dalam Proses Penanaman Kedisiplinan Terhadap Remaja Di Dusun Krajan, Desa Gembong, Kecamatan Arjosari, Kabupaten Pacitan Tahun 2015 sebagai berikut:

1. Kedisiplinan belajar remaja di Dusun Krajan, Desa Gembong, 
Kecamatan Arjosari, Kabupaten

Pacitan tahun2015 belum

disiplin. Remaja laki-laki akan

belajar ketika diperintah terlebih

dahulu dari keluarga atau orang

tua, ketikaada tugas sekolah atau

PR (Pekerjaan Rumah), dan akan

menghadapi ulangan. Tidak ada

kesadaran dari remaja laki-laki

sendiri untuk belajar.

2. Peranan keluarga dalam proses penanaman kedisiplinan belajar terhadap remaja di Dusun Krajan, Desa Gembong, Kecamatan Arjosari, Kabupaten Pacitan tahun 2015 yaitu membimbing, mengarahkan, mengawasi, membiasakan dan menasihati.

\section{DAFTAR PUSTAKA}
Abu Daud. 2010. Faktor-Faktor Yang Mempengaruhi Disiplin Belajar (http://abudaud/blogspot.co m/faktorfaktor/yang/Mempe ngaruhi/disiplin/belajar.htm, diunduh 23 Maret 2015).

Andarmoyo Sulistyo. 2012 Keperawatan Keluarga Konsep Teori, Proses Dan Praktek Keperawatan. Yogyakarta: Graha Ilmu.

Ani. 2010. Individu Keluarga Dan Masyarakat. (http://anie0804.wordpress.c om.individu-keluarga-danmasyarakat $/ \mathrm{htm}$, diunduh 23 Maret 2015).

Arikunto Suharsimi. 2006. Prosedur Penelitian Suatu Pendekatan Praktik. Jakarta: Rineka Cipta.

Basrowi dan Suwandi. 2008. Memahami Penelitian Kualitatif. Jakarta: Rineka Cipta.

Daryanto dan Suryatri. 2013. Pendidikan Karakter di Sekolah. Yogyakarta: ArRuzz Media.

Djamarah Syaiful Bahri. 2004. Komunikasi Orang Tua dan Anak dalam Keluarga. Jakarta: Rineka Cipta.

Djam'an Satori dan Komariah A'an. 2012. Metodologi Penelitian Kualitatif. Bandung: Alfabeta. 
Emzir.2011. Metodologi Penelitian Kualitatif Analisis Data. Jakarta: PT. Raja Grafindo Persada.

Hamdani. 2011. Strategi Belajar Mengajar.

Bandung:Pustaka Setia.

Lexy J. Moleong. 2012. Metodologi Penelitian Kualitatif. Bandung: Remaja Rosdakarya.

Margono. 2010. Metodologi Penelitian Pendidikan. Jakarta: Rineka Cipta.

Nasution. 2012. Metode Research. Jakarta: PT. Bumi Aksara.

Shochib Moh. 2010. Pola Asuh Orang Tua dalam Membantu Anak Mengembangkan Disiplin Diri. Jakarta: Rineka Cipta.

Slameto. 2010. Belajar dan FaktorFaktor yang Mempengaruhi. Jakarta: Rineka Cipta.

Subagyo Joko. 2004. Metode Penelitian dalam Teori dan Praktek. Jakarta: Rineka Cipta.
Sugiyono. 2009. Memahami Penelitian Kualitatif. Bandung: Alfabeta. 2009. Metode Penelitian Kuantitatif Kualitatif dan $R \& D$. Bandung: Alfabeta.

Sutopo. 2002. Metodologi Penelitian Kualitatif. Surakarta: Sbelas Maret University Press.

Tulus Tu'u. 2004. Peran Disiplin pada Perilaku dan Prestasi Siswa.Jakarta: PT. Gramedia Widiasarana Indonesia.

Undang-Undang Dasar 1945. 2009. Solo: Al-Anhar.

Undang-Undang.Sisdiknas No 20 Tahun 2003. 2003. Jakarta: Sinar Grafika. 